Portland State University

PDXScholar

$5-18-1970$

\title{
Automated Information Retrieval Systems for Legal Research
}

Robert G. Baylor

Portland State University

Follow this and additional works at: https://pdxscholar.library.pdx.edu/open_access_etds

Part of the Business Administration, Management, and Operations Commons Let us know how access to this document benefits you.

Recommended Citation

Baylor, Robert G., "Automated Information Retrieval Systems for Legal Research" (1970). Dissertations and Theses. Paper 648.

https://doi.org/10.15760/etd.648

This Thesis is brought to you for free and open access. It has been accepted for inclusion in Dissertations and Theses by an authorized administrator of PDXScholar. Please contact us if we can make this document more accessible: pdxscholar@pdx.edu. 
AN ABSTRACT OF THE THESIS OF Robert G. Baylor for the Master of Business Administration presented May 18, 1970.

Title: Automated Information Retrieval

Systems for Legal Research

APPROVED BY THE THESIS DIRECTOR:

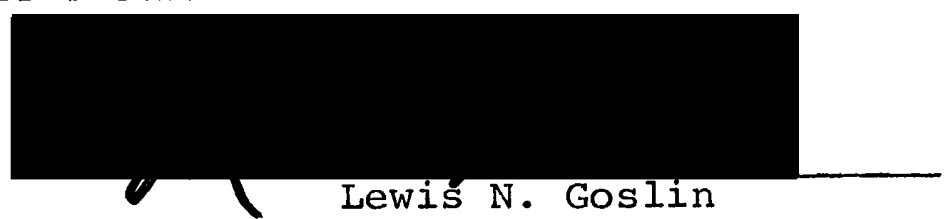

Purpose. This study of automated information retrieval systems was undertaken to attempt to ascertain the extent and development of a total legal information system.

Overview. Historically, lawyers have searched the statutes and case law in the traditionally manual method. Given consistent high standards of editing, not too complex materials, and a collection of manageable size, this manual method will work to reasonable satisfaction, so long as a document never changes in meaning or significance. Lawyers point out that the present manual system is inadequate because with 30,000 new judicial decisions and 15,000 new statutes being promulgated each year it is becoming increasingly difficult to search the law.

Methodology. The writer surveyed a selected sample of legal firms to determine the methods or aids used in the area of major management concern: (1) word processing, 
(2) bookkeeping, (3) timekeeping, (4) library, (5) filing, and (6) legal research. Correspondence and interviews revealed that only five firms are using a mechanical search system, while only one firm was on-line with a computer legal research system. Because law firms began addressing themselves to administrative problems only since 1960, it was necessary to make an investigation of the literature to develop an information base for this study. The proceedings of national law office management seminars were studied. Interviews were held with law firm managers, interested lawyers, the Chief Clerk of the Supreme Court of Oregon, the Administrator for the oregon Justice Department, and computer and accounting system salesmen.

Discussion. The use of the computer as the tool to use in a system for automated information retrieval for legal research was first demonstrated in 1960 at the American Bar Association's Annual Meeting in Washington, D. C. Several experiments and studies conducted since that time are discussed in this study. Two new systems seem to offer significant promise for automated legal searches, (1) the OBAR System, and (2) the Aspen System. Each is computeroriented and offers full text ("word for word") searches. Resistance by lawyers to use an automated legal research system is expected due to professional conservatism.

Recommendations and Conclusion. Law firms must continue upgrading their administrative functions in order to be ready for a sophisticated automated information retrieval 
system. A national organization such as the American Bar Association will have to organize a joint effort for implementation of a full information system. Law school curriculum will have to include a study of system analysis and computer technology. Law firms will have to develop a new concept of organization and work habits will need to be changed. The use of automated information retrieval systems for legal research will make lawyers more efficient and more profitable, without the need to increase client fees. 
TO THE OFFICE OF GRADUATE STUDIES:

The research director approves the thesis of Robert G. Baylor presented May 18, 1970.

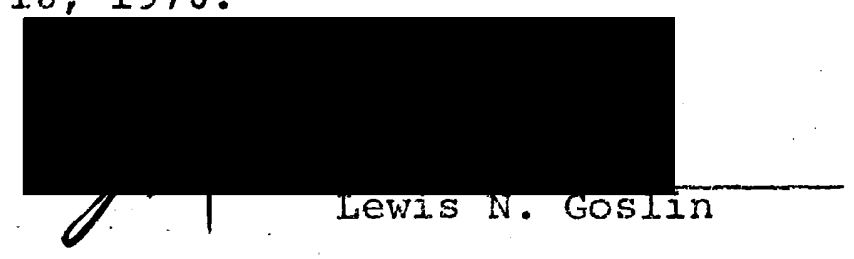

APPROVED :

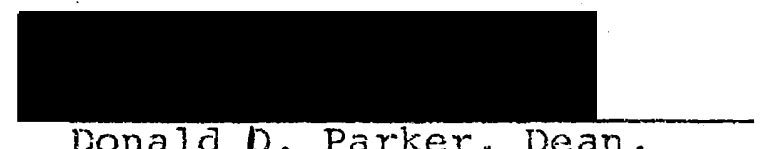

Donald D. Parker, Dean,

School of Business Administration

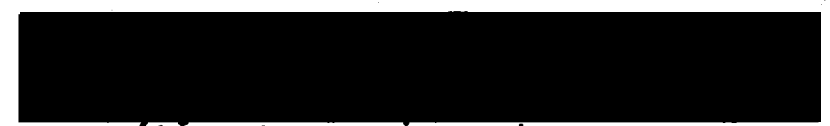

Frahk Roberts, Acting Dean

of Graduate Studies 
AUTOMATED INEORMATION RETCIEVAL

SYSTEMS FOR IEGAI, RESEARCII

by

ROBERT G. BAYIOR

A thesis submitted in paxtial fulfillment of the requirements for the degree of

MASTER

of

BUSTMESS RDMINISTRATION

Fortland State University

1970 
TABLE OF CONTENTS

Page

CHAPTER

I. INTRODUCTION AND OVERVIEW ....... I

Introduction .......... 1

Purpose of the study......... I

Problem ............ 1

Backgrouna--General . . . . . . 1

The Need for an Information System : 3

Mechanical Aids .......... 3

The Information Age....... 3

Discussion ........... 4

General . . . . . . .....4 4

Barriers to Understanding:.....4 4

Structural Definition ....... 5

Management Functions . . . . . 5

Significance of the Study . . . . . 7

Significance ....... . 7

Research Methodology ....... 7

outline of the study....... . 8

II. GENERAI, COMMENTS ON INEORMATION

STORAGE AND RETRIEVAI SYSTEMS . . . . 9

Background . . . . . . . . 9 9

Introduction . . . . . . . 9 9

Need for Information Retrieval ... . 9

Information and Data ...... 10

Compendium of Equipment. . . . . 11

Summary . . . . . . . . . 11

Retrieval kequirements . . . . . 12

Purpose . . . . . . . . . 12

Genera1.......... . . 12

Types of Research and Retrieval . . 14 
$\underline{\text { Page }}$

Office Information . . . . . . 15

The Computer System ....... 16

Summary ........... 16

III. AUTOMATED INFORMATION SYSTEMS

FOR LEGAL RESEARCH . . . . . . . 18

The Computer in the Practice of Law - 18

Introduction ........ 18

Computer systems . . . . . . . 19

Other Coriputer Uses ....... 20

Some of the Experiments ..... 20

The ABA study . . . . . . 20

The Plan ............ 21

Conclusions of the Report ..... 21

Point of Law . . . . . . . . 22

KWIC ...... ........ 23

Western Reserve University .... 23

Datatrol Corporation ....... 24

University of F'lorida Computer Center 24

Some Other Current Projects . . . 24

Miscellaneous Projects. . . . . 27

The OBAR System . . . . . . . 27

Introduction ......... 27

Full Text Approach ........ 28

Some OBAR costs . . . . . . 29

The Aspen System . . . . . . . 29

Introduction . . . . . . . . 29

Applications ......... 30

other Stored Legal Information . . 31

Search Technique ........ 31

Conclusion . . . . . . . 32

Sumnary . . . . . . . . 32

IV. PROPOSED INTEGRATED ILEGAL

INFORMATION SYSTEM ......... . 33

The Critical Criteria . . . . . 33

Introduction . . . . . . . 33

Essential Characteristics .... 33

The Ereakthrough . . . . . 36 
Page

The Proposal . . . . . . . 37

Inherent Problems : . . . . 38

Adninistrative Problems . . . 38

Natural Resistance....... 39

Factor for Change ........ 39

Slow Transition ........ 39

Advantages of Integrated Legal

Information ......... 40'

V. CONCLUSION AND RECOMMENDATIONS . . . 42

Administrative Efficiencies . . . 42

The Need to Improve . . . . . . 42

Recommendation ........ 42

Automated Information Retrieval

For Legal Research ........ . 42

Two Needs .......... 42

Available Technology . . . . . . 43

High cost of Conversion ..... 43

Recommendation ......... 43

Need for Education . . . . . . 44

Leadership by the ABA ..... 44

Recomnendation ....... 45

Required Changes .........45

Firm Organization and Work Habits 445

Recommendation . . . . . . 46

Conclusion . . . . . . . . 46

VI. A LOOK INTO THE FUTURE : . . . . . . 46

Review ............. 46

Introduction . . . . . . 46

The outlook ......... 47

Areas of Application . . . . : . 47

Scope of Application . . . . . 50

Degree of Integration with other

Systems ......... 50

Degree of Automation . . . . . 51

Development of a General System

Theory............ 51 
Page

Conclusion .. . . . . . . 52

ANNOTATED BIBLIOGRAPHY . . . . . . . . . . 54

APPENDIX A A REVIEW OF THE CORRESPONDENCE : . . 66

Table I--Data .......... . 70

APPENDIX B COMPENDIUM OF EQUIPMENT AND TECHNIQUES 76 
CHAPTER I

INTRODUCITON AND OVERVIEW

\section{INTRODUCTION}

Puxpose of the study. The study will consider automated information retrieval systems for legal research, and will attempt to ascertain the extent and development of: a total legal information system. A selected sample of legal firms will be surveyed.

Problem. Since the fixst national conferences on law office economics were held in 1965, many law firms have paid more attention to upgrading their administrative problems. As these problems have been resolved, the need for a comprehensive information system for the law firm has become apparent. Few law firms have such a system because of tider lack of faniliaxity with business systems and their concem over possible conflicts between the firm's system and the inaividual methods of its professional peopie.

Bactgrourd--General. Whenever lawyers congregate, they start asking each other questions, ana exchanging ideas about economic practice and procedures. During the early $1940^{\circ} s$, the American Bar Association (ABA) published four articies on "Law office Organization," which have now gone through seven editions. A questionnaire at that time produced responses that rated in fourth place the need for articles on law office organization. The earliest articles 
written in 1.926, by Dwight G. McCarty, (32) and Reginald Heber Smith, (16. Introduction) have been reprinted throughout the years, and are considered basic to law office management. But it was not until the first national conferences on law office economics were held in New York City. (38) and in Chicago, (5) 1965, that the legal profession made a concerted effort to establish a base for improving the business methods of law firms. The ABA acknowledged as early as 1960, that law firms were managing their "business" not much different than the "horse and buggy days." A 1961 economic study for attorneys in the state of oregon (10) indicates that lawyers have not kept up with the times in business methods. Continuous studies of the economic problems of lawyers emphasize that the individual lawyer must look to himself for a substantial portion of the cure. (5; 6; 7; 38) A 1968 study by Paul G. Ulrich, (7. pp 195-2.26) indicates that even though many law firms have made a substantial effort to increase the efficiency of aministrative? systems they have neglected one of their most critical needs, which is a workable information retrieval system for their own work product. Mr. Ulrich indicates that a law office information retrieval system is normally at the low end of the scale in terms of inputs and outputs, and orly when the information needs become sufficiently laxge enough in volume and frequency can a law firm consider computer-oriented retrieval systems. 
The Need for an Information System. Need for an information storage and retrieval system of some kind should be obvious. The mass of documents as well as the ever in-creasing dependence upon those documents, makes it necessary to find better ways for storage and retrieval. Morris I. Cohen, (4. pp 183-194), points out that with 30,000 new judicial decisions and 15,000 new statutes being promulgated each year, an information system is necessary to provide prompt and accurate reports of current status and authority. The practice of law is becoming increasingly complex, both as to the body of the law and the intricacy of the facts. Mechanical Aids. For many years the only mechanical equipment law firms used were typewriters and adding machines. Many firms today have little else in the way of office equipm. ment, but more firms are acquiring copy machines and autom matic typewriters. Vexy few have their own Automatic Data processing or Electronic Data Processing Equipment. Several. business firms and government agencies can now accomplish by computer searches of 1 aw, or other legal information. Experiments in storing and retrieving legal information are discussed in chapter III.

The Information Age. We are now in the advent of another era, which the literature characterizes as the "age of information." New techniques will be required to govern information storage and retrieval. The growth of these new techniques has provided business firms with better information systems. Demard from law office clients for faster, 
more efficient service requires that lawyers use better tools and techniques. (31)

II. DISCUSSION

General. Prior to 1965 no national survey studied the management problems of law firms. Several state Bar organizations conducted their own survey. Those survey results indicated the need for a more positive direction for law office management. The 1965 ABA Conference was in part., a response to that need. All state studies were economios oriented, and the rate of response to questionnaires mailed (72\% in Oregon) (10) indicated high attomey interest. Little interest was expressed toward the development of "systems"--be they accounting, timekeeping, or information systems. Lawyers, like other professionals, tend to xebeI at the idea of conformity implicit in the idea of a system. The primary goal of any "system" for the lawyer is more efficient, economical service to his cilent. The attainment of this goal will give the individual lawyer more time to develop his professional competence, more remuneration for his professional services, and less concern over purely routine matters. (26)

Barriers to Understanding. According to Mr. David Fried of the ABA (Interview--December 1969), there are probably less than 100 firms in the country working on information systems. The study of a system is difficult because of the diffuse terms being used in the literature. 
Writers are still groping for a "common" definition. Some other barriers to understanding are:

1. The new awareness by lawyers of the subject matter,

2. The fact that everyone seems to be doing something different, and

3. A distinct difference between the ostensible ara real goals of an information system.

The objective is to improve legal research and information processing. A genuine information system will rem guire changes--jn firm organization, management attitudes and prilosophies, and in utilization of time.

Structural Definition. An information system is conm prised of five components:

1. Data gathering,

2. Information storage and retrieval,

3. Analysis,

4. Communication and transmission,

5. Information presentation.

Management Functions. The major areas of management concern in a law office can be viewed as:

1. Wora processing--the daily production of the finished manuscript, including drafting, revising, comparing and proofing, finalizing and duplicating, and completion of mailing, delivering, and filing with the proper official, or client. 
2. Bookkeeping-the accounting system used for the maintenance of the firm's monetary transactions, inciuding trust accounting, client disbursements, and the billing function.

3. Timekeeping--the system by which the lawyer is able to keep track of the chargeable hours invested in client matters, and the means of recapturing that in ventory of time for preparing the legal services billing.

4. Libraxy-the procurement, circulation, and majntenance of reference materials, the interfiling of current looseleaf services, and the control systern for location finaing and retrieval of those materials. This includes work product opinions, and memoranda as well as a.11 legal research applications.

5. Filing-the system by which the attorney is able to find information respective to specific dient matters, including opening of che file, interfiling, indexing, docketing, locating, retrieving, replacing, closing, and storing client files, either active or inactìve.

6. Legal Research--the method and technique employed to search case law, and to retrieve office-produced information.

These six basic functions are the essence of the lawyer's business. Yet evidence $(5 ; 6 ; 7)$ as confirned by the correspondence, indicates that many lawyers: do not keep time recoras, have an inadequate bookkeeping system, 
do not have any control over their library materials, are not aware of their word pxocessing failures, and are unable to easily control or find materials or records in the files.

\section{SIGNIFICANCE OF THE STUDY}

Significance. The importance of a study of ari automated legal research system is becoming more apparent each passing day. Information retrieval is the process by which attorneys gather information. As demands on their time become greater, attorneys must find faster ways to do their legal research.

\section{RESEARCH METHODOLOGY}

The writer has used both primary and secondary research to develop an information base for this study. Sources consulted include: the American Bar Association"s Proceedings of the 1965, 1967, and 1968 National Conferences on Law Office Economics and Management; intervjews with managers of law firms, the chief clerk of the supreme court of Oregon, and the Administrator for the Justice Department of Oregon; correspondence with law firms; interviews with interested attorreys; and interviews with computer and accounting salesmen. An investigation has been made of secondary source materials concerned with the subject.

Briefly, the procedure used in gathering information for this study was: 
1. Analysis of the literature to determine what has been written on the topic.

2. Interviews with managers of law firms.

3. Correspondence with fixns selected on a sample basis, determined by their participation in national law office conferences. See Appendix A for a discussion of the correspondence.

4. Attendance at the National Law office Conferences in New Orleans and San Yrancisco, and attendance at the oregon state Bar Convention in 1969.

5. Interviews with directors of the American Bar Association, Chicago, Illinois.

V. OUTLINE OF THE STUDY

$\begin{array}{ll}\text { Chapter I - } & \begin{array}{l}\text { Introduction and overview } \\ \text { Chapter II- }\end{array} \\ \begin{array}{l}\text { General Conments on Information } \\ \text { Retrieval Systems }\end{array} \\ \text { Chapter III- } & \begin{array}{l}\text { Automated Information Systems for } \\ \text { Legal Research }\end{array} \\ \text { Chapter IV- } & \begin{array}{l}\text { A Proposed Integrated Legal } \\ \text { Information System }\end{array} \\ \text { Chapter V- } & \text { Conclusion and Recommendations } \\ \text { Chapter VI- } & \text { A Iook Into The Future }\end{array}$


GENERAL COMMENTS ON INFORMATION

STORAGE AND RETRIEVAI SYSTEMS

\section{BACKGROUND}

Introduction. Information is the essential ingredient which every lawyer neeós to analyze his case. An examination of information systems properly should begin with the present state of the art. Many books have been written about computer technology, computer programning, systems engineering, systems design, and systems analysis, but virtually none have been written about the information storage and retrieval problems of law firms. It has only been during the second (1966) and thixd (1968) National Conferences on Law Office Economics and Management that the problem of information storage and retrieval has been considered. The fourth conference, to be held in New York City in May 1970, will again consider the problem. It was therefore necessary to examine the literature relative to the salient characteristics of an information retrieval system for the "business world" to determine if such charac" teristics are appropriate for the information needs of the legal profession.

II. NIEED FOR INFORMATION RETRIEVAL

Some of the important factors contributing to the 
need for development of an information retrieval system are the steady increase in technical progress and the growing volume of abstracts, trade joumals, law school reviews, case law, and regulatory rulings (many of which are dedicated to increasingly detailed areas of specialization). The sheer volume of 30,000 new judicial decisions each year (4) is overwhelming by itsejf.

In an Aspen Systems Corporation news release dated April 15, 1969 (J. Walter Thompson Company News), it was reported that over $200 \mathrm{milli}$ ion words are contained jn the statutes for all 50 states. Manual search techniques are incapable of correlating all the state statutes. Information is being made available too fast, with not enough time available to read, understand, or retain much of it. As specializations intensify, the problem of bridging the gap between disciplines becomes increasingly difficul.t.

\section{INFORMATION AND DATA}

"Some writers make a distinction between data and information, whereby the former refers to a mass of unstructured facts, and the latter to structured facts assembled in a meaningful fashion." (41. p 54) A good deal is written in the literature about information and data, and writers tend not to differentiate clearly between the two concepts. One of the clearest distinctions is set forth by williams (49), who points out that the significant difference between information and data is that data is 
manipulated and transformed, while information normally is unaltered and remains in context.

It is clear that we must carefully differentiate between "information systems" and "data processing systems." This paper is primarily concerned with "information systems." The legal profession has only recently recognized the need for administrative improvements (incluaing "data processing"), so many lawyers use the terms "data" and "information" interchangeably. Additionally, it must be pointed out that data may be raw material from which information is produced. Such produced "information" may well be "data" of a subsection which in turn will produce "in-formation."

Compendium of Equipment. For the purpose of presenting information to lawyers, Appendix $B$ sets forth the spectrum of equipment that is available for mechanical aids to data and information systems.

Summary. This discussion of an information system presupposes the use of computers. The sophistication and technology of equipment is constantly changing, so each law firm should not have to custom design its own system. This is necessary because the system must be flexible enough to keep up with current computer technology. As technology changes; so will the information system. The five basic uni.ts in a computer system are: (1) input devices, (2) central processing unit, (3) certral storage, 
(4) output devices, and (5) controi unit.

Since users (lawyers) are all searching the same materials (statutes, regulations, xulings, etc.), the information system should be a uniform one. Rather than each firm attempting to develop a unique system, joint effort will help create a broader base system, with lower per user cost.

\section{RETRIEVAL REOUIREMENTS}

Puxpose. The purpose of this section is to describe the sjgnificant characteristics of an information system for lawyers. The basic assumption is that the majox objective of an information system is to bring relevent information in usable form to the right user at the right time so it will help in the solution of the user's problems. Thus, the development of an information system consists of: translating a user's needs into a design for, and eventually the creation of, a physical configuration of facilities, personnel, communications, and equipment.

General. This system is concerned with the two major areas of "information" for lawyers:

1. The search of the statutory and case law, and

2. The search and retrieval of work products previously done within the law office.

A. Search of statutory and case law. Normally included are three basic searches: 
I. State
(a) Constitution
(b) Revised statutes
(c) Decisions of the Supreme Court and Court of Appeals
(d) Trial court decisions
(e) Administrative rules and regula- tions.

2. Federal

(a) U. S. Constitution

(b) U. S. Code

(c) U. S. Supreme Court decisions

(d) Circuit court or District Court decisions

(e) Agency rules and regulations not otherwise specifically covered.

\section{Other States}

Searches similar to own state search, as in 1 above.

B. Law office information retrieval. The system would include all office-generated memoranda, briefs, opinion letters, and research notes. When prepared, each would be coded and filed according to an index system which would permit selective location and retrieval of the documents. With proper indexing, the documents should be easily available. 
Types of research and retrieval. Manual research and retrieval has long been the normal way to gather information. Automated systems can provide lawyers with accurate, fast, comprehensive, and economical ways of doing research. Some known systems are:

Automated (computerized) legal research. In recent years many advancements have been made in the use of computers in management, administration, accounting, and information retrieval systems. Many of the "hardware" and "software" systems for these activities have been adapted for the use of lawyers $(12 ; 13 ; 31)$. Some have been adapted to legal research. These computerized legal research systems are of two general types:

1. Indexed systems. These are systems in which indexed information sinilar to that of the West Key Number and Digest system is stored in a computer. The information can be retrieved for review by the lawyer if he knows the jndex title.

2. Full Text systems. The full text system is a recent development for the legal profession. (12) Full text of the material ("word for word") is stored in the computer. This approach appears to be more flexible for the lawyer. A researcher can initiate inquiries without referring to preestablished phrases or numbers. One such system now in use in Ohjo is the OBAR System, operated by Data Corporation, 7500 Old Xeria Pike, Dayton, Ohio 45432. 
Another operating system is Aspen Systems, The Webster Ha11. Pittsourgh, Pannsylvania 15213. The Aspen System is the outgrowth of a project started in 1956 to compile a treatise on hospital law at the University of Pittsburgh Health Law Center.

The inpetus for creating or modifying an information system generally arises from:

1. The firm's desire to improve an existing system,

2. Improvements brought about from advancing technology, and

3. Improvements detected in the course of Iongrange planning.

Office Information. Apart from the need for an overall system to search case law, there is a need for a method by which to retrieve office-produced information. Historically, firms have used an inadequate index card system. The correspondence and interviews indicate that most firms have difficulty agreeing as to which index method to use, i.e. the Harvard System, or West Key Number, or any other suggested system. The McBee Keysort system has been used successfully by small firms, but as needs and complexities increase, that system has proven deficient. Most firms do have some kind of a system, but the correspondence indicates that all firms surveyed are anxious to find a better one. 
The Computer System. During the design of the computer system it is important that the system designer and the ultimate user work closely together. Frequently misunderstandings develop between them. Almost as often the problems are not resolved to the satisfaction of either. Both the designer and the user should be aware of the fact that information systems generally never have enough capacity. Due to the rapid change of technology, changes are often necessary, so the mechanisms for accomodating change must be available. Too often capacity problems pass by default to the system operator, who may lack the ingenuity to solve them.

Summary. The need to design a system with a great deal of elasticity is essential in that technology is changing every day. When evaluating information processing equipment, and the size of the information bank, lawyers must provide for both present and future contingencies. They must plan for increased workloads both in volume and complexity; they must be able to consider the modular use of equipment in order to add new peripherals; and they must be able to maintain an educated guess regarding future developmerics.

In order to get the most from the computer, it may be necessary to merge the administrative data processing functions with the information processing functions. With the present body of state statutes containing 
over 200 rillion words, and over 30,000 new judjcial decisions each year, lawyers need a more efficient method to process new information. Adding to these, legal abstracts, administrative rulings, and law school reviews, it can be seen why lawyers are having a difficult time absorbing all the information. The use of a computer seems to be a logical approach. 


\section{AUTOMATED INFORNATION SYSTEMS FOR IJEGAI RESEARCH}

\section{THE COMPUTER IN THE FRACTICE OF LAW}

Introduction. An examination of the utility of the computer as the tool to assist lawyers in their research must start with an examination of lawyers' research materials and needs. It is ciear that lawyers use a variety of materials covering a wide xange of subject matters and topic headings. Lawyers are concerned with library research. They must have a means by which to access the statutes and judicial decisions, books on the subject, and treatises which comment upon the precedents. There is an ever-growing volume of precedents, and the job of indexing, let alone searching out the reguired precedents, is becom-m ing more and more complex. Unfortunately, many lawyers are unable to perform more than a cursory examination of the precedents. Frequently they will spend many unproductive hours digging through indexes, trying to turn up leads.

Once the attorney gets into the area of decisions, rulings, and regulations, at both state and federal agency levels, the problem of covering all the ground becomes almost unmanageable. Another source contributing to information in the field are law school reviews. The problem 
of gathering together, comparing, and evaluating all of this information becomes an impossible one when attempting to correlate it by hand.

Additionally, law offices produce a large volume of research notes, opinions, memoranda, and briefs. Frequently this valuable information is "lost" because of inadequate indexing and ever poorer filing.

Computer systems. During the past two or three years axtomation has been used for some portions of law office information needs. Two main approaches exist. One approach is that of using full text as input to the computer system; the other is essentially an indexing system to be placed on the computer. The indexing method uses an index prepared by people who read the documents and assign one or more index texms to each item. These index terms and the citation are placed in computer readable form and added to the information base of the complter research system. The other approach uses the full text of the document as the input to the computer system, thus permitting the computer to construct a searching file of the document. According to John F. Horty, Jr. (12. p 53), the first demonstration of the applicability of the computer to legal research occurred in 1960 at the American Bar Association's Annual Meeting in Washington D. C., when the searching of statutes was demonstrated. Two systems, the Ohio State Bar Association Automated Legal Research 
System (OBAR) and Aspen Systems, will be discussed later in this paper.

Other computer Uses. In addition to using the computer as a vehicle for searching out and retrieving "the law," there are other types of "information" that can be most conveniently handled by the computer. Trial lawyers and courts are plagued by docket control problems: trial number assignment, plaintiff and defendant identification (paxticularly when there are many plaintiffs or defendants involved fin a multiplicity of charges), names and addresses of witnesses, the complexities of subject headings and topical phrases, and the control of the court calendar, all present special problems. The planning of estates, tax problems, general court administration including jury management, legislative redistricting, congressional activity, keeping track of government "policies" and administrative law, are all "information" concepts that lend themselves to computer applications. It would seem to be inevitable that the use of the computer for legal research and information storage and retrieval will become a nondebatable question, merely because of the sheer volume and ever-growing complexity of the law.

\section{SOME OF THE EXPERIMENTS}

The ABA Study. The American Bar Foundation and the International Business Machines Corporation in 1963 engaged in a joint investigation of the application of electronic 
information processing equipment to the handing of legal materials. wheir study represents a part of a larger American Bar Foundation project which deals with an analysis of legal research methods and materials in general. The study was presented in 1963, entitled "The computer as a Tool for Legal Research." (19) The pilot work and basic experiments in automatic organization and retrieval of: legal literature was discussed. Correspondence with the American Bar Foundation (December 1969) indicates that after presentation of the paper, the project ran aground. Not much more was produced after that point in time.

The Plan. The overall plan for the pilot experiment was to convert raw text to machine-readable form. The steps planned for the experiment were:

1. Conversion of text to machinereadable form.

2. Machine construction of a thesaurus ("index word space").

3. Abstracting and indexing.

4. Searching.

5. Recognition.

Conclusions of the Report. The report draws up some general characteristics for an ideal system for storing and retrieving legal literature. As pointed out by the authors, the characteristics are ideals, which may be and probably are less than totally obtainable, but they do express an objective. The four characteristics are: 
1. Information should be stored, based on language rather than indexing.

2. Updating and correlation of the information should be a computer function.

3. A wide variety of searching strategies should be available.

4. The user should be able to approach directly the store of information.

Point of Law. The "Point of Law" approach as developed in 1952 by the late Robert G. Morgan, an assistant professor of business law at oklahoma state university, is another technique. (20.p 85) It is an automated system using a key number approach. The system has three operational features which distinguish it from conventional manual methods.

1. The system is capable of searching for numerous "concepts" at one time.

2. All the law is searched in answer to each query, so when no response is recejved, there is a fair degree of certainty that no precedent exists on that particular question.

3. The researcher may select the type of output he wishes in answers to his request. The Point of Law approach has served as a stepping-off place for research into automated storage and retrieval of case law. 
KWIC. Another early experiment (1956) in information storage and retrieval was the "Key Word In Combination" system developed at the University of Pittsbuxgh by John F. Horty, Jr. (20.p 87) His group at the Health Law Center turned to the development of new research tools when their primary research tasks became overburdening. In the Pittsburgh system, the full text of state statutes is entered into the computer via magnetic tape, with each section of the statute treated as a document identified by an index number. Searches are accomplished by the researcher himself. He selects words which he believes would appear in a statute touching upon his problem. The pittsburgh system was the first to bring computer capabilities to bear on legal research problems. This system is oriented purely toward language, relying solely upon the actual words used by the statute writers. Professor Horty subsequently established Aspen Systems corporation. Their corporate goal is to store, retrieve, and reproduce any information desired--faster, more accurately, more comprehensively and more econornically than by traditional searching methods. Western Reserve University. Another interesting experiment was conducted by the Western Reserve University Center for Documentation and Communication. (19. p 90) In some respects it is similar to Robert Morgan's demonstration, that is, searching is carried out via computer using an index prepared by human handlers from original text. However, the indexing method is not conventional, 
at least not from the point of view of the lawyers accustomed to the West Key Number System. The Western Reserve University coding system embodies a considerable refinement of analysis over most indexing systems. Its indexing depth probability is greater than that of most conventional systems.

Datatrol Corporation. Experiments with the participation of the Datatrol Corporation utilizing association factors and mathematical concepts have been conducted. (20. $p$ 92) It appears that none of these mathematical approaches have been particularly significant for the legal profession; though a good deal appears in the licerature about such experiments for general purpose library use. (1; 14) There may be a meeting of the disciplines in this area at some future time.

Univexsity of Florida Computer Center. Citations to all Florida legal periodicals were computerized in 1967.

(48) Although designed for expansion to include treatises, no further mention in the literature has been made of this experimental system.

Some Other Current Projects. (12) There are several significantly large computer-based information system projects at federal, state, and regional levels which have been designed to improve law enforcement activities. All of these are in various stages of analysis, design, implementation, and operation; each is also being continually improved. The more notable of these projects are: 
1. The National Crime Information Centex (NCIC), operated by the FBI. Its chief function is to provide a data base on stolen property and wanted persons, accessible through remote terminals by police agencies throughout the nation. Its main processor consists of two JBM $360 / 40$ computers.

2. Automatic State-wide Auto Theft Inquixy System (AUTOSTATIS), operated by the California Highway Patrol. This systen provides a data base on stolen and wanted vehicles, accessible through remote terminals by law enforcement agencies in california and adjacent areas. It is linked to NCIC and uses two IBM 7740 computers.

3. New York State Identification and Inteligence System (NYSIIS), operated by the State of New York. Its main purpose is to provide a data base on individuals with arrest and conviction records and other intelligence type matters. It will be accessible by law enforcenent and correction agencies, and uses IBM $360 / 40$ and Burroughs $B-5500$ computers.

4. Washington Area Law Enforcement Systems (WALES), operated by the District of Columbia. WALES has a aata base on motor vehicles, operators, licenses, and other police information. It is accessible by law enforcement agencies in the District of Columbia and adjacent areas and by the District motor vehicle department. It uses an IBM $360 / 40$ computer. 
5. The st. Louis Police Department Information system is a system for acquisition, storage, retrieval, and communication of data on accidents, emergency calls, criminal incidents, officer activity, and summonses. It uses IBM 7040 and IBM 7740 computers to support police operations in and arourd st. Louis.

6. The Chicago Police Department system, operated by the Chicago police Department. This is primaxily a manual. information system which uses unit record equioment and a smal1 IBM 1410 computer to expedite police cominand, control, and record keeping for police operations in and around Chicago.

7. The Kansas City Automated Law Enforcement Response Team (ALERT) System for the storage, rapid retrieval. and display of data on wanted persons, suspects, and individuals with criminal records. It also contains information on license numbers of cars owned by wanted persons and of stolen vehicles. Serving the 316 square mile area under. the jurisdiction of the kansas city police, the system uses an IBM $360 / 40$ computer coupled to IBM 2260 visual display terminals in each of the seven police zone headquarters. The so-called Omnibus crime control and safe streets Act of 1968 (P. L. 90-35I), with the funding it makes available for innovations of this and other types at all levels of government, will provide added stimulus for continued development and introduction of computer-based information systems fox law enforcement and criminal justice purposes. 
Misceliareous projects. The Air Force has placed on tape the full text of decisions, both published and unpubJished, of the comptrolier General of the united states and the published court martial reports. The court of Appeals of New York is expeximenting with inputting its jualcial decisions in full test. There is a project also under way to computerize city ordinances for search, revision, and publication. Law Research Service of New York City has established a computer research service which uses an indexing approach. In that system indexes to various judicial decisions have been placed in machine-readable form and through the use of a thesaurus the user could ask questions of the system.

\section{THE OBAR SYSTEM}

Introduction. As mentioned earlier, the ohio state Bar Association has worked on a computer information storage and retrieval system for the legal profession. The Ohio Bar Eutomated Research (OBAR), which is a joint venture between the ohio state Bar and the Mea Corporation, went on-line (October 1969) with an information bank being accessed by 10 terminal units located throughout the state. One terminal is in the attorney general's office, while the other nine are scattered among private law firms. The Ohio State Bar Association became convinced that the use of the computer was the way to develop an information system. They launched a major program in 1966 to make the capabilities of 
the computer available to ohjo lawyers. In utilizing the OBAR system, the lawyex need know nothing about electronics. All he needs to know is law.

Full Iext Approach. The law placed in the computer is entered in full text--it is not abstracted or digested. Every word of every sentence in a case or statute is placed in the computer. Iritially, all Ohia case law plus the Ohio Revised Code and constitution were put into the conputer's disi storage. Later, othex material will be added. very simply, the computer is used as an extremely rapia readex of the jegal matexial. It has the ability to recognize any word or combination of words specified by the lawyer who gives instructions to search the law. Not only can the computer recognize a statement of law the lawyer has given it (and tell him whether or not that statement of law appears on material stored in the computer memory), it can also tell him in what case the statement appears. If the attorney wishes, the computer can also print out the full text of the case or statute. The computer does not answer questions; it does not analyze law. It searches through a vast body of material and retrieves for the lawyer those cases or statutes which contain language bearing on the problem with which he is concerned. In effect, it is a vastly superior index created new for each problem the lawyer presents.

Once the lawyer becomes familiar with the teletype terminal, he can usually find in a matter of minutes case 
or statute law which previously mi.ght have required several hours, or in some cases even days, to find. Once the cases or statutes are located, it then remains for the lawyer himself to make his professional analysis of the legal material.

Some OBAR Costs. During February $1970 \mathrm{Mr}$. James D. Vandegrift, office manager for the Oregon state Bar, visited an $O B A R$ demonstration at the $A B A$ miciwinter meeting in Atlanta, Georgia. In his memorandum of March 10, 1970 he reports that approximately $\$ 1,250,000$ has already been invested in conversion costs and development of the system. On-Iine users are charged $\$ 100$ per hour for actual computer time. Also, the user pays about $\$ 100$ per month for his own telephone costs and rental of teletype equipment. The Mead-Data Corporation has available, in lieu of the teletype, a console with a Cathode Ray screen and fast printer at a monthly rental of $\$ 350$ per month. Mr. Vandegrift is convinced that automated legal research with the full text system is a dynamic new tool for lawyers, law schools, law libraries, and the legal profession. He reports that the Oregon Bar is considering recommending this new concept.

\section{THE ASPEN SYSTEM}

Introduction. Mr. Vandegrift has made available his file of correspondence with the Aspen Systems Corporation. Sales literature and correspondence (1969-1970) indicates that as of April 15, 1969, wi.th the development of 
theix system 50, the corporation has successfully computerized the largest body of full wext information ever stored in a computer, the storage of statutory Laws of 50 states. Aspen System 50 search results come in whatever form a lawyer wants, from computer printout to computerized photocomposition ready for the printer.

Applications. According to their sales literature, Aspen System 50, as a new information product, has immediate value to all levels of government and to industry, as well as to lawyers.

1. State statutes- -200 separate agencies of the federal government can now easily find conflicts in existing state legislation.

2. National corporations-provides up-to-theminute knowledge of ever-changing statutory law (packaging, safety, etc.).

3. Trade associations and other lobby groups--all of the current state information relative to the association's interest.

4. Insurance companies--must know insurance statutes for each state; also must know which states have laws favorable to a new type of real estate investment.

5. State governments--will afford legislators more creative time by timely providing all relevant information. 
Special applications of Aspensearch are also available. Mr. John S. Hall's letter of April 27, 1970 indicates that Aspen has: indexed and codified office materials for some clients, aj.ded in preparing the index to the new Revised Statutes of Hawaii, created special litigation files for lawyers, and aided in bill-drafting processes.

Other Stored Legal Information. In addition to the statutes of the 50 states, Aspen systems has put into computer disks for storage and retrieval: the United states Code; United states Supreme court and circuit courts of Appeals decisions; Internal Revenue Code and Regulations; and various other federal, state, and municipal legal information. It also publishes the "Hospital Law Manual." Aspen Systems also provides custom-tailored legislative reporting and other specialized legal information retrieval services.

Search Technique. Searches are available on the full 50 states, any one of five regions, specialized files such as the 10 largest industrial states, or individual states. Search output can be full text printout, context printout, or citations from the computer. The system is maintained in a current status by a special. UPDATE file. Additionally, by means of Aspen's wholly owned subsidiary, Aspen Computype, the text material retrieved from the search can be photocomposed and bound in hard copy book form. 


\section{CONCLUSTON}

Summary. With the evex-growing volume and complexity of the law, faster, more efficient ways of retrieving information must be found and utilized. Two such methods have been recently developed by OBAR and Aspen Systems. Both systems appeax to be well constructed, and the literature indicates that both are acceptable to users. It will be necessary for an overridjng association, such as the Amexican Bar Association, to make a study of both systems and formulate a recommendation to enable the profession to use a common system. 


\section{A PROPOSED INTEGRATED}

LEGAI INEFORNIATION SYSTEM

\section{THE CRITICAL CRITERIA}

Introduction. The volume of literature currenily being addea to the storehouse of legal information offers cause for concern over the inadequacy of presently used techniques and tools for finding the law. Most lawyers presently can create a hypothetical case that will resolve his client's problem. Then, by studying the method used to label the documents in the library, he can attach imaginary labels to his hypothetical case and search for actual cases bearing the same labels. This is essentially how lawyers now perform research in case law with the existing manual tools. Given consistent high standards of eaiting, not too complex materials, and a collection of manageable size, this system will work to reasonable satisfaction, so long as a document never changes in meaning or significance. But lawyers point out that present manual systems are inadequate. $(1 ; 7)$

Essential Characterj.stics. Certain characteristics of an "ideal system" for finding law were postulated in Chapter III. They were offered tentatively and with dissidence. It is now possible to postulate a refined set of characteristics for the ideal law finding system, which we 
can label the "critical criteria."

1. The notion that the ideal system should be based on language rather than subject matter still appears to be a sound approach. One way of achieving a language-based system is to store unindexed raw text in a "disaggregated information base." There are, however, certain obvious ana other not so obvious arawbacks in unindexed storage. The advantages of a language-based system probably can be preservea and some of the drawbacks of indexless storage avoided if we can develop a system in which a nachine constructs an index with absolute consistency in objectivity. Two types of advantages result from indexing. First, there may be advantages in economy such as a shortening of the time lapse between the recognition of a need for information and satisfaction of the need. Second, there are advantages in the utility of the system to the user, such as increased assurance of complete retrieval of relevant documents and reduction of the burden on the questioner to know the answer to his question. Language-oriented machineconstructed indexes based on linguistic statistics hold promise for the ideal system.

2. A built-in capacity for automatic large-scaled reorganization and updating is essential where any form of indexing or classification is used. The construction of such routines is clearly feasible for the computer when the indexes to be reorganized have been constructed originally by machine according to consistent and objective 
routines.

3. An examination of the research in the field of automated law-finding confirms the suggestion that there needs to be a wide variety of possible searching strategies. In the systems that have indexes, the searching strategies are index-oriented and thereby limited. The strategies are oriented solely toward the occurrence of a word, a particular word, and that word must be known to the questioner.

4. The requirement that the questioner be able to address the storage of information directly is not relaxed by the introduction of an indexing system into the list of ideal characteristics. Consideration of the systems now underway, however, does suggest that it is naive to state the requirements so simply. The system should allow the questioner to address the computer directly, and it should not require him to describe that which he does not know. It should be enough to describe the periphery of the whole in his information, and then ask the system to fill in the blanks.

5. The research already accomplished suggests a new capability for the ideal system. There are advantages to semantic and syntactical analysis and the elucidation of meaning which should not be ignored. (14) If we can achieve a significant portion of such analysis by automated means, we can retain those advantages while eliminating the 
disadvantages stemming from the subjectivity of an analysis performed by humans.

\section{THE BREAKTHROUGH}

Interviews in December 1969 with Mr. David Fried and Mr. Richard Temporo, directors of the American Bar Foundation in Chicago, indicate that most people involved in the search for a good information and storage retrieval system for law firms are generally convinced that the OBAR approach is a significant "breakthrough." Almost to the man, everyhone who has been exposed to that system feels that it probably is the best working and easiest system brought to the attention of the legal profession during the past 10 years. Because tre OBAR system is relatively new, there is virtually no literature available. This system has not been on-1ine long enough to prove whether or not it will be completely workable, but all early indications are chat it will be.

The only major concern seems to be the cost of computerizing new information. No survey has ever been conducted in the United States to determine the number of hours invested by every attorney in the country in legal research. Economic studies all point out that every lawyer should be investing approximately 1500 chargeable hours per year. What portion of that time is actually consumed by antiquated and inefficient research methods is completely unknown. given an average value of $\$ 30$ per hour for a lawyer's time, and 
the fact that there are literally hundreds of thousands of attorneys throughout the nation spending some large proportion of their time in information searches, it would seem to be reasonable to assume that many millions of dollars are annualiy "lost" through inefficient searching techniques.

III. THE PROPOSAL

In light of the technological success of the OBAR system and the Aspen System, the legal profession should considex utilizing a centralized computerized full text information system. Sponsorship will have to be spearheaded by the American Bar Association or some other national legal organization, in order to break down lawyer resistance to change. Massive legal information will have to be converted into the computer bank. Fifteen or 20 sub-systern computers should be located on a regional basis to handle law office retrieval (office memos, research notes, etc.) and court docketing problems. Each of these regional computers could serve as a subpart of the total system, thus relieving the master computer of local details. The master computer would have the responsibility for maintaining all statutory and case law. A computer network system shoula be developed with inter-ties between the various regional computers and master file computer. For example, if a regional computer were to be established in Oregon, it would serve lawyers and courts for the States of Oregon, Washington, 
Idaho, Wyoming, and Montana, while an additional two computers might be required in California to serve the remaining western states. Other computers would be strategically located throughout the remajning regions of the country. Each regional unit would contain information relevant to its geographical area. As an attorney inquixed the regional computer, giving the parameters of the information needed, the regional computer could communicate with the master computer.

A computer network system would be highiy integrated and extremely beneficial to the legal profession.

\section{INHERENT PROBLEMS}

\section{Administrative Problems. Law firms are still trying} to resolve their management and administrative problems. This will present the greatest stumbling block to establishment of a national legal information system. Law firms are normally "managed" by the senior partner, or a management committee comprised of several members of the firm. The lawyer is also concerned with practicing the law. As a result there is little time to manage the firm properly, and virtually no time to consider the possibility of utilizing mechanical aids to improve the administrative efficiency of the office. Traditionally, lawyers have relegated to an untrained secretary or file clerk the responsibility to organize and maintain all of the internally generated information. Reliance has also been placed upon professional 
services to provide indexes and related headnotes to get into statutes, case laws, and treatises.

Natural Resistance. It is anticipated that a great deal of resistance will be generated toward the use of the computer because of reluctance to break with traditional. methods. The greatest proportion of practicing attorneys today are not familiar with simple data processing systems. It is easy to understana their natural reluctance to consider something as "mysterious" as a computerized inform mation systen.

Factor for Change. A factor for change will be the element of time. Attorneys that are enthusiastic about using the computer for information searching are generally the younger attorneys who have been accustomed to computers "in everyaay life." Also, concerned law office administrators are convinced that the computer is the only solution to the ever-growing information problems of the legal profession. Several state Bars have already investigated the use of computer data processing. $(7 ; 21 ; 31)$ The more forward thinking are aware of and concerned about the "information explosion" problem.

Slow Transition. Because of natural fear and reluctance, aue in great part to the conservative nature of the legal profession, American Bar Association directors have been suggesting a step-by-step approach. Given the underlying philosophy of "crawling before running," Messrs. Fried and Temporo, as well as others, have been trying for several 
years to help law firms throughout the country upgrade their administrative functions. Firms are now going to various levels of sophistication using administrative aids, such as automatic typewriters and electronic accounting machines. National legal seminars and conventions include in their symposiums some discussion of computex use. The presentations have been either so sketchy or so sophisticated that lawyers have not been convinced of the significance of the computer.

\section{ADVANTAGES OF INTEGRATED LEGAL INFORMATION}

One of the important characteristics of the proposed information system is that it must be computer oriented. The logical structure of the computer network will make it possible to have the computer perform the necessary information storage and retrieval functions, linking all of the various regional computers into one "master" integrated system.

In the long run, the computer will do the research job less expensively (ox in a shorter time, which results in less expense) than the traditional manual methods. It seems that the computer will be the only possible vehicle for handling the ever-growing volume of legal information. In many situations, human effort, unaided by the computer, will be too slow and too inaccurate to produce useful results. Most businessmen decide to use a computer because it will reduce the cost of a job. In many instances, however, 
the really significant benefits are by-products which cannot be measured in dollars and cents.

As an example of speed and accuracy, Mr. David Fried advised the writer of a demonstration of the OBAR system. An attorney wished to find a specific landmark case, and to have a printout of the case. The attorney had previously conducted a manual search that took seven hours of research. Given the fact situation, the computer located the case in less than 15 minutes, adäitionaliy printing out a list of relevant cases that were decided on the basis of the landmark case.

The legal profession will have to weigh the benefits of using the computer-oriented information system on other than a cost savings criteria. Some of the benefits of the system, which may be difficult to quantify, are: (1) speed, (2) economy in volume, (3) accuracy, (4) ability to handle extremely large volumes, (5) interpretation, (6) legible uniform results, (7) the benefit of the network size, and (8) "instant" communication. 
CHAPTER V

\section{CONCLUSION AND RECOMMENDATIONS}

\section{ADMINISTRATIVE EFFICIENCIES}

The Need to Improve. During the 1960 's, law firms throughout the nation initiated steps to accomplish administrative efficiencies. As indicated at national conferences, confirmed by survey results displayed in Appendix A, many firms still have a long way to go. There will always be a need to improve acministrative functions. Fixms are still groping with resolutions to "routine" problems, e.g. the kind of indexing system to use for their files, what types of file hardware to select, how to best "manage" the firm, how to maintain lawyers' time investments ard how to bill, and how to develop more qualified staff support.

Recommendation. A professional firm must have an efficient business system as a foundation for the successful conduct of its practice. The business system requires a competent administrator to direct all nonlegal services. Management of the firm would then be free to concentrate on policy matters and long-range planning.

\section{AUTOMATED INFORMATION RE'TRIEVAL FOR LEGAL RESEARCH}

Two Needs. There is a need for an information retrieval system in two areas of the law: (1) searches of statutory 
and case law, and (2) law office products. Several techniques and experiments were discussed in Chapter III with a proposal presented in Chapter. IV. Law firms traditionally have attempted to develop retrieval systems for their office product but have done little to consider other than manual methods for case law retrieval.

Available Technology. Unitl 1969, the concept of computerized law searching was regarded by most lawyers as just that: an interesting concept, but not practical. The technology necessary for a computerized search of the law now exists. At least two systems, OBAR and Ispen, have demonstrated the speed and quality of computer searches of the law. The low cost per search (estimated to be in the $\$ 20$ to $\$ 50$ range) should be less costly than manual searches. High Cost of Conversion. OBAR has already invested $\$ 1,250,000$ in conversion of the law to its information bank. The cost of converting for the Aspen system is not known by the writer but because it already includes the statutes for all 50 states the cost is probably well in excess of OBAR's. Much more law must still be prepared for the computer's information bank.

Recommendation. Individual law firms will be slow to accept a new innovation such as automated information retrieval for legal research due to reluctance to break with traditional methods. Additionally, in light of the high conversion costs, law firms cannot afford to develop their own 
system. Therefore, a national organization such as the American Bar Association will h have to organize and conduct a joint effort to coordinate development of an integrated legal information retrieval system. Representatives of all state Bar associations should participate in ordex that they may inform and advise their members. Large firms should initially experiment with computerized searches by mail. Results of their experiences should be made available to their state Bar organization. If results are favorable, the firm should then install a terminal unit to perform their own search framing.

\section{NEED FOR EDUCATION}

Leadership by the $A B A$. A massive educational program will have to be organized by the American Bar Association. Ultimate users (lawyers) will have to be convinced of the benefit, speed, and reliability of computexized searches. Information about the system must be disseminated to the profession. Lawyers will need to learn how to use the computer-oriented system. Some law schools are already offering courses or seminars in "Computer and the Law' (Boston, Cornell, Houstor, Illinois, Nebraska, Oklahoma, Pennsylvania, Rutgers-Newark, Virginia, Case-Western Reserve, and Pittsburgh). Professor Reed Dickerson (12. p 180) reports that few law faculties have anyone capable of teaching jurimetrics. Ore step has already been accomplished by the preparation of the ABA's Readings in Jurimetrics. Still more must be done. 
Recommendation. The curriculum of law schools will have to be expanded to include instruction in system analysis and computer technology. Almost all universities have a computer which could be used for legal research and for experimentation in some of the applications of the computer technology to law offices. Exposure to the new technology will do much to remove the fears that exist in the profession about use of the compiater. Thus the conmunication gap between technicians and lawyers will be closed, by providing law students the opportunity to work with computers on laworiented applications.

\section{REQUIRED CHANGES}

Firm Organization and Work Habits. A lawyer now manually labors through the library searching case and statute law. He then turns over the fruits of his labor to his secretary-typist for drafting and redrafting. The law firm has been a combination of lawyer and secretary. In light of technological breakthroughs (automatic typewriters, data processing equipment, and automated legal searches) the firm will have to review its organizational structure, management attitudes and philosophies, and utilization of time. The distribution of authority in a law firm partnership is not a critical choice in terms of the financial success of the firm. The response to computer technology may be the critical element. Legal research, via the conventional manual method, is a great consumer of the lawyer's time. 
A complete new concept of organization and work habits will. have to be developed if the firm plans to successfully incorporate use of the computer-oriented search technique.

Recommendation. Law firms must learn to develop a satellite of personnel around the lawyer in order to allow him to develop and utilize his professional competence to the fullest degree. In order to do this, they will have to break with such traditional "standards" as one lawyer-one secretary. A lawyer specialist should be free to have time to learn to use the computer-oriented search techniques now available. Consequently, he will spend less time in the library and will have more time avajlable to resolve his client's problems.

\section{CONCLUSION}

Lawyers need to be made aware of the advantages of automated information retrieval systems for legal research. An educational process as recommended will help. Demonstram tions of working systems (such as OBAR and Aspen) at national and state conventions will dispel must of the mystery about computer-oriented search systems. The use of automated information retrieval systems for legal research will make lawyers more efficient and in many instances, more profitable, without the need to increase client fees. 
A LOOK INTO THE FUTURE

\section{REVIEW}

Introduction. The application of computer network planning to many kinds of legal storage and information retrieval problems provides a significant link between the dynamics of time-consuming actions and all other information requirements of the legal function. In the future, the use of the computer will be applied to new areas of endeavor. Integrated information storage and retrieval systems will be made possible through master file definition, proper identification and coding to correlate all files, and computer automation of file updating and report generation. These developments will lead to the establishment of a general systems theory for the legal profession.

The previous chapters have discussed and attempted to explain some of the basic problems of developing an information storage and retrieval system for the legal profession, particularly in light of the fact that the 1960's were devoted primarily to upgrading the administration function. This chapter is devoted to a discussion of the future systems.

An information storage and retrieval system is a tool that should be used for action. It provides a means for recording and conmunicating all of the laws, statutes, 
decisions, administrative rulings, and other related legal information. The systematic discipline inherent in the system approach forces proper indexing, planning, and monitoring of information.

\section{THE OUTLOOK}

Several dimensions of the proposed information system can be expanded by the legal profession, including:

(1) the areas of application, (2) the scope of application within an area, (3) the degree of integration with other legal information systems, (4) the degree of automation, and (5) the development of a general systems theory for projects, law office management, and legal research.

1. Areas of Application. In addition to the applications already discussed, the basic technjque of utilizing a computer as a master file for storing and retrieving legal information should be broadened to cover many other new areas of interest for the profession. Every industry and every government agency is constantly adding to its own information storehouse. It is safe to say that the legal profession will be able to aid these other disciplines. As new laws are stored in the computer memory, information should then be available to "customers" other than lawyers. Industry. Corporate marketing departments will need a thorough and up-to-date knowledge of state laws. The subjects to be searched vary widely and include corporate law, product warranty, packaging, work environment, liability 
for occupational diseases, pollution control, consuner finance, and medical assistance.

Insurance companies. Although the laws governing insurance are usually found grouped in state insurance codes, there are numerous instances where relevant laws are hidden in other codes. A master file of all laws contained in the computer can be guickiy searched.

Trade associations. Ready access to state statutes can help them promote favorable legislative changes within a specific state.

Government. Many writers have commented upon the need for computerized information systems for the federal and state governments. (12. pp 80-116) Some specific applications are:

A. Court administration. In addition to processing data for clerical purposes, the computer can be used to analyze information for judicial managerial purposes. Justice information systems (multicourt information) would automate all civil and criminal dockets in the region, incluaing integrated judicial files. Past trial court cases within the jurisdiction (unresearchable case law today) could be stored in the information system.

B. Legislative redistricting. Totaling of population to assume equal population districts is a simple but tedious and repetitive process, ideal. 
for a computexized information system.

C. Congressional activity. Budgetary information and the statutes authorizing legislative bodies' fiscal responsibility could be correlated.

D. Legislation. Current information on all present laws relating to proposed bills and resolutions.

E. Basj.c government rules, policies, and administrative law.

F. Tax administration. A possible tieline with the Internal Revenue Service's Automatic Data Processing Master File system, to help analyze needed changes in tax law.

G. Law enforcement and criminal justice information, as a means for improving those processes.

Real property. Attorneys need to make comprehensive searches of land records.

Ultimately the information system will be able to encompass many other new areas of application. The use of an information and storage retrieval system could also be used in phases of financial functions. As each firm prepares a proforma profit and loss staternent on a regular or quarterly basis, such information could be set into the system to develop relevant statistics. The information could be transmitted back to participating law rirms.

A comprehensive system would be extrenely useful in handling complex projects, or new legal issues, as they arise. For example, the legal and financial actions required 
to arrange, organize, and consummate highly complex corporate mergers and acquisitions could be planned by using the information system.

The time involved in legal research should be greatly reduced, thus optimizing the legal expertise of the attorney. Wherever planning, analytical evaluation, and massive data and information banks are concerned, a computerized information and storage retrieval system can be of value.

2. Scope of Application. A second dimension in which the information system will be increasingly used in the future relates to the scope of the application for particular law firms. As firms learn to use the computer information system they will broaden their use of it. The benefit from the information and storage retrieval system will increase directly as the scope of the system itself increases.

3. Degree of Integration with other Systems. A thirc way in which use of the information system will increase is the degree to which it is integrated with other related information and management systems. Data and information from other systems should be integrated with this system, as law affects many different disciplines. It would be reasonable to assume that the system could introduce key elements of time and sequence of action into all of the related systems revealing what actions must be accomplished, when, and in what sequence. More complete integration of these present systems would greatly improve the validity 
and credibility of information in this system. The specific pattern which this integration will follow is not clearly evident, however. Artificial barriers blocking the free flow of data and information among the legal profession and other disciplines must be eliminated to achieve a new total system. Specific points of attack for this purpose should include: (1) a master file which should include a total file of information and data encompassing all aspects of the law, (2) coding schemes which should be predicated upon a common base, integrated and unambiguous throughout the profession, (3) automatic file updating in order to provide a continuous flow of input information, and (4) report generation which should be flexible and able to respond to fast response (on-line, real-time).

4. Degree of Automation. This assumes the use of large mass-storage data devices with direct access, including the use of such innovations as cathode ray tube display equipment and "light pencils."

5. Development of a General System Theory. The automated and integrated information system proposed in chapter IV will enable lawyers to do significant research into any legal question. In the past, much of the data and information available to attorneys has too often been incomplete or made available too late to be used in arriving at the proper legal conclusions. The systems approach will offer an increasingly "real-time" picture of the law. Attorneys have had to develop great talent for making intuitive judgments, 
or for assessing the variables and unknowns in the law by rules of thumb, shrewd guesses, and sharp feelings. In the future a computer infornation system will force them to think more explicitly and analytically, and help them to formalize their decision-making processes. The use of the system should help them arrive at better decisions, given certain sets of circumstances, in a more expeditious manner. The development of a general systems theory should be undertaken by the American Bar Association. Linked with computer processing, continuous remote input, and dynamic aisplay, a total legal information system would provide attorneys with all relevant information. Further, as continued efforts are made to describe and analyze operations using these techniques which have an almost limitless capability to integrate data and information, the profession should expect fundamental, irrevocable changes in the organization of firms, in the types of skills required to be a lawyer, and in the processes necessary to educate oneself for the profession. The concept of an automated master information system is a new and untested concept. The approach may have. such fundamental effects that the profession should conservatively expect to have profound, social, political, economic, and legal impact on a vast spectrum of human endeavor in the years to come.

Conclusion. The word "Jurimetrics" was suggested in 1949 by Nr. Lee Loevinger (12. pp 179-180) as a useful word 
for activities involving the scientific investigation of legal problems. The underlying concept and spirit of this chapter could well be sumned up in that one word, "Jurimetrics." Included in the definition of the term is the use of advanced technological methods for legal research, and advanced mathematical techniques such as the application of mathematical logic to predict the results of liti gated cases. Lawyers seem likely to benefit also from a general acquaintance with decision theory, symbolic logic, semiotic and general analysis. Combining these with a general introduction to computer technology covers most of what many now call the field of "Jurimetrics." 
Annotated Bibliography

1. American Association of Law Libraries. Proceedings

Fif.th Biennial A.A.L.L. Institute for Law Librarians, Cambridge, Massachusetts, 1961.

Directed by Mr. Earl C. Borgeson, Harvard Law School Iibxary, this institute was concerned with literature of the law-techniques of access. Professor John F. Horty's address regarding legal research using electionee techniques gives a clear explanation of the application of machine capacities to meet clearly defined legal research problems and a demonstration of the machines at work. (pp. 56-68.) Significant differences: thoroughness, speed, total accuracy, and eventually the maneuverabijity of the electronic devices available.

2. American Bar Association (Editor). The Lawyers Hand-book, st. Paul: West Publishing Co., 1962 .

A practical handbook, which is the resulting product of a cooperative effort by the $A B A$ and several state Bars. The handbook is essentially "administratively" oriented, and does not directly concern itself with "information" needs.

3. American Bar Association. Modern Equipment Makes the Lawyer Money, St. Paul: West Publishing Co., 1960 .

The primary purpose of this pamphlet is to aid in improving the lawyer's services to his clients. Secondly, it is aimed at improving the profitability of the law office.

4. American Bar Association. proceedings of the Joint Meeting of the ABA Special Committee on Electronic Data Retrieval and the $\overline{A B A}$ Standing Committee on Economics of Law Practice, Philadelphia, August 6, 19.68. As reprinted in the Jurimetrics Journal, June, 1969.

This joint meeting focused attention on the working habits of lawyers and judges, and the "computer tools" they need now and will need in the future.

5. American Bar Association. Proceedings of the First National Conference on Law Office Economics and 
Management, Chicago, 1965.

Lawyers by nature balk at efficiency, and generally are not adaptable to change. This First Conference goes beyond the usual "bread and butter" programs normally presented to lawyers. Included are discussions of systems approach and the need for better management.

6. American Bar Association. Proceedings of Its Second National Conference on Law Office Economics and Management, New Orleans, April 6-8, 1967.

Useful as background to help build a base for understanding the administrative problems of managing a law firm. The paper presented by Robert P. Bigelow on "Computer Aids for the Law office" includes in its appendix a discussion of case law searching by machine.

7. American Bar Association. Proceedings of the Third National Conference on Law Office Economics and Management, San Francisco, October, 1968 .

Diverse subject matters inclusive of problems which continue to present themselves at state economics seminars. Includes three presentations of particular interest:

(1) Brice, Bil1. "Law Office Management Information systems."

(2) Horty, John. "The Computer in the Library."

(3) Ulrich, Paul. "Law Office Information Retrieval."

8. American Management Association. Establishing an Integrated Data processing system - Blueprint for a Company Program, New York, 1956.

This report has been adapted from material originally prepared by the National Management Services Division of Ernst and Exnst for AMA orientation seminar on data processing systems. It contains several case studies. The foundation of the integrated data processing program is described in this book. The author points out that it does not inevitably mean investment in a large computer or the use of a far-fiung communications network to transmit information to and from widely scattered plants or sales offices. 
9. Archibald, Russell D., and Villoria, Richard L. Network-Based Management Systems (PERT/SPN), New York: John Wiley \& Sons, Inc., 1967.

Planning, scheduling, and control of complex interrelated business activities and of the resources (time, money, manpower, machines) required to execute those activities are the main concern of this book.

10. Baerncoff, David A., and Dole, Donald A., A Survey of the Economics of Law Practice in Oregon, 1961, Eugene, Oregon: University of Oregon, Bureau of Business Research, 1963.

The report traces the effects of several important variables on lawyers' incomes. To some extent the results of the study provide clues to the economic potentials that lawyers may reasonably anticipate. The report covers only economic matters.

11. Becker, Joseph, and Hayes, Robert M. Information Storage and Retrieval; Tools, Elements, Theories, New York: John wiley and Sons, Inc., 1963.

The purpose of this book is to provide an overview of all of the aspects of the field of information storage and retrieval, and how they relate to each other. The book is intended as a roadmap, guiding the newcomer through the maze of scattered development that has characterized the early growth of this field of information storage and retrieval.

12. Bigelow, Robert. P., ed. Computers and the Law,

Chicago: Commerce clearing House, Inc.

(a) First Edition, 1966

(b) Second Edition, 1969.

An introduction to the state of the art in the use of computers by lawyers. In law, the main use seen for computing machinery, apart from the usual office work, is the retrieval of legal matexials--statutes, administrative ruljngs and judicial opinions. The Second Edition is updated with articles by more current contributors.

13. Bigelow, Robert P. "How Lawyers Can Use Computers to Practice Law--Now." Law Office Economics and Management, Vol. X, No.3 (November, 1969), 
pp. $250-264$.

A description of some current computer applications for law firms, and indications of future uses: (1) computerized tax services, (2) legal research, including OBAR, (3) litigation, (4) estate planning and management, (5) automatic typing.

14. Borko, Harold. Automated Language Processing. New York: John Wiley \& Sons, Inc., 1967.

This book is about one of the valuable byproducts of the quest for automatic translation: the lively area of basic research on how to apply computers to the study of language and how to use them in data processing presented as natural language texts. By focusing on a statistical analysis and on syntax, it concentrates on the areas in which the most solid and intelligible work to date has been dorie.

15. Bourne, Charles P. Methods of Infornation Handling. New York: John Wiley and Sons, Inc., 1965.

This book provides a description of the tools, equipment, and methodology that might be applied to the problems of understanding and designing an information system. Whenever possible, the chapters are sprinkled with cost estimates.

16. Cantor, Daniel J., ed. Managing the Law Office: Organization, Systems, Records and Fees. Mundelein, IJlinois: Callaghan \& Company, 1964.

A compilation of selected materials related to the title. This book provides a basic body of knowledge and background material in respect to law office management. Included are "Inanual methods," and simple concepts of ADP, statistical computations, and microfilm applications.

17. Carter, Launor F. National Document Handling Systems for Science and Technology. New York: John Wiley \& Sons, Inc., 1967.

This book is an outgrowth of a study undertaken for the Committee on Scientific and Technical Information Task Group on National Systems for Scientific and Technical Information in support of their examination of national document and 
information systems. The initial and primary priority of the book is placed on national systems relating to documents, their handling and the management of such documents.

18. Collison, R. L. Information Services. Iondon: James Clarke \& Co. Ltd., 1950.

The organization and administration of information services is the subject of this book, which is a library-oriented treatise. A first-class libxarian should be capable of providing a good library service for any specialized body of users and a specialist nonlibrarian will never provide a good library for anyone--because librarianship is a persliasive technjque.

19. Doss, M. P., ed. Information Processing Equipment. New York: Reinhold publishing Corporation, 1955.

Somewhat out of date now, this text does at least present the basic equipment available in the information-processing field. The material is essentially "production" oriented, rather than "search and retrieve" oriented. Some discussion is devoted to the use of punch cards, and the development of numerical data-handling machines.

20. Eldridge, William B., and Dennis, Sally F. "The Computer as a Tool for Legal Research." Law and Contemporary Problems, Winter, 1963. Duke University School of Law, Durham, N. C. (Reprinted from the Symposium on Jurimetrics, 1963.)

A paper presented by members of the joint investigation team dealing with an analysis of legal research methods and materials. The emphasis in. the study is on the method of organization of material. In particular, the researchers are trying to design a system that combines the merits of nonclassification with those of classification, in an "untouched-by-human-hand" procedure.

21. Furth, Stephen E., "Computer Uses in the Law Office." Oregon Law Review, Volume 49, Number 2 (February 1970), pp. $217-223$.

The author, a participating member in the standing Committee on saw and Technology of the ABA, and 
currently Manager of Information Systems Marketing at IBM, reviews generally the possible applications of computer-based data processing services, in the practice of law. He divides his discussion of applications into four groups:

(1) administrative; (2) services to the lawyer, to provide better access to items in the files; (3) computer-assisted legal services, e.g., tax work, estate planning; and (4) legal research, including a discussion of the new OBAR system.

22. "Galion: Blueprint for a Total. Management System." Modern Office Procedures, February, 1970, pp. 1623 .

A systems man telis how he installed a total computer system, and the maragement tells why they are glad he did it. A new concept. What makes the MIS at Galion so different are four outstanding features: (1) the "one-clexk" concept (the computer); (2) put all current data on-line, available to all levels of management; (3) keep only one master file, and organize it so that only one transaction is necessary to update all sections of the file; (4) keep data storage on disk in one-third the space normally used in most systems through the use of a master file concept, compressed alpha file and the chaining technique.

23. Gleason, Fred. A Yardstick for Legal Records and Information Retrieval. Chicago: Matthew-Bendex, Inc., 1965.

The author conducted a survey of the filing systems of approximately thirty-five law offices varying in size from sole practitioners to large firms. Chapter IX, "The Coming Revolution in Law Offices Research--Information Retrieval," is particularly significant for this study, as j.t aiscusses the dawn of a new era, information retrieval via the computer.

24. Hayes, David G., ed., Readings in Automatic Language Processing. New York: American Elsezier Publishing Co., Inc., 1966.

This book is a compilation of papers that the editor feels epitomizes, in their various ways, methoas, solutions to central problems, or approaches to the use of the computer as a processor of natural language. 
25. Heyel, Carl. Computers, office Machines, and the New Information Technology, New York: The Macmilian Company, 1969.

A basic text covering information processing in the computer age. Includes a broad list of equipment, pictures, and illustrations. Particularly see the chapters devoted to total systems, and to Data Banks.

26. Hoisington, R.E., and Nagler, P.M. "Business Management in the Modern Law Firm," The Arthur Young Journal (Autumn, 1969), pp. 21-27.

Successful management of a modern law firm requires that the partners (1) recognize that their firm is, among other things, a business, (2) make certain they implement an efficient business system, and (3) employ a professional administrator to insure proper use of the business system and that the firm's resources are effectively administered.

27. Hourigan, Andrew, Jx. "Today's Lawyer in a Changing Society," Proceedings of the Third National Conference on Law Office Economics and Management, San Francisco, 1968, pp. 1-8.

The law itself is constantly changing, too many lawyers have not kept up with the fact that changing times are really affecting the day-today practice. Lawyers must seek those management and professional skills which are prerequisite to handle the changes being thrust upon law firms.

28. Kent, Allen, ed., Electronic Information Handling, Washington, D. C.: Spartan Books, InC., 1965.

Speakers drawn from many fields of government, education, and industry presented papers at a. national conference held in 1964. This book is a reflection of the proceedings. The papers were organized into six sections:

1. Analysis of the field,

2. End uses of information,

3. Operational experiences,

4. Large- scale systems under development,

5. Shortcomings of electronic information handling systems,

6. Planning for the future. 
29. Lewis, Orme., and McAlpin, Kirk. Docket Control. Chicago: Matthew-Bender, Inc:, 1965.

An Economics of Law Practice series pamphlet, prepared by the standing committee. The experience of this committee suggests that the difficulty of maintaining an adequate control of the numerous day-to-day obligations of the average law office is one of the primary problems of the profession. This experience also suggests that the average practitioner does not have a satisfactory system.

30. Link, David $T$. "Law Office Management and the Computer," Law Office Economics and Management, Vol. $\mathrm{X}$, No. 3(November, 1969), PP. 241-24A.

A bxief discussion of the "total systems approach" as used by one law firm. Essentially concerned with administrative problems.

31. Iong, Raymond.J., Esq. Nonconventional systems and Equipment for Law office Economics. Chicago: Matthew-Bender, Inc., 1965.

This pamphlet is not presented as a completed treatise on the use of nonconventional equipment in the practice of law. It is intended to serve as an introduction to this subject for the practicing lawyer, to illustrate one practical application of data processing in law office administration, and to such other phases of 1 aw practice to which it may be applied.

32. McCarty, Dwight. Law Office Management. New York: Prentice-Hall Inc., Thixd Edition, 1955.

McCarty's book, first published in 1926, has been characterized as being the most comprehensive text in the field of law office management. The author was among the foremost of lawyers pointing out the inefficiencies and neglect in law office administration. A "classic" in the field of Law office management.

33. Meadow, Charles T. The Analysis of Infornation Systems; A Programer's Introduction to Information Retrieval. New York: John Wiley and Sons, Inc., 1967 .

Supplies the background needed for participation 
in the analysis and design of informationhandling systems and for unclerstanding the literature in the field. The emphasis is on how languages and files can be organized to make the communication between a seeker of information and the data base, more effective.

34. Miller, Rodney W. "Equipment and Office Supplies," Economics of Law Practice, Spring, 1966, pp. 2133 .

Concerned with administrative techniques and procedures, the committee recommends that law offices should standardize their office equipment and supplies.

35. O'Bfien, William R. "Modexn Office Systems-Their Place in Law Firm Managenent," Case \& Comment, Vol. 74 , No. 5 (September-October, 1969). pp.

Valid operational data are essential to the effectiveness of the business function of every law firm. If the system is built to meet the needs of the firm, a management information system can meet these data needs.

36. Orren, Harding A. "Walk Before You Run," Law Office Economics and Management, Vol. $X$, No. 3 (November, 1969), Pp. 245-249.

A suggested step-by-step application approach for law firm recordkeeping, via the computer.

37. Pederson, Dale L., and Brownhill, Thomas E.

"Administrative and Financial Management,"

Economics of Law Practice, Spring, 1966, pp. 3551 .

Regardless of size of office, the same management functions must be performed. Possible solutions are offered, showing how decisions can best be made, what controls are desirable, the various systems which are available, the reports and data which can be accumulated, and how to use the same.

38. Practicing Law Institute. Edited Forum Transcript on Managing Law Offices, New York City, May 1965.

An inquiry into often overlooked problems of office management. Twenty-six specialists-- 
managing partners, corporate law department heads, insurance experts, and computer consultants--discussed recurrent administrative problems, and described and evaluated attempted solutions. Some attention was paid to computer systems for accounting.

39. Rosove, Perry E. Developing Computer Based Information Systems, New York: John Wiley and Sons, Inc., 1968.

This book describes selected aspects of the process by which computer-based information systems are developed. The focus is on the human factor and the interdependence of it with other elements in the system development process. The book is about information, as distinct from data. The author contends that information is the concept relating data which are otherwise meaningless, to some specified human purpose or objective.

40. "Rush Retrieval with Mechanized Filing." Modern Office Procedures, February, 1970, pp. 33-36.

A buyer's guide and specifications chart on mechanized files, including conveyors, rotaries, and automatics. Here are facts for selection.

41. Sinclair, John M. "Basics of an Information System," The Office (February 1970).

The elements needed in an information system, and how to go about getting a system put together.

42. Sloat, Clark, and Fitzgerald, Richard. Administrative and Financial Management in a law Firm. Chicago: Matthew-Bender, Inc., 1965.

Concerned with administrative and finaricial controls, which are basic to equitable and adequate fee determination. Chapter III, dealing with a "Guide to Development of Basic Management Reports," emphasizes the bookkeeping aspect of management concepts.

43. Smith, Cullen, and Cljfton, N. S., "Income of Lawyers, 1965," American Bar Association Journal, Volume 55 (June 1969), pp. 562-564. 
The published results of the Internal Revenue Service's statistical sampling of lawyers' incomes for 1965. Even though the statistics leave gaps, the available data does provide sound source material on the economics of the profession.

44. Smith, Samuel V.; Brien, Richard H.; and Stafford, James E., ed. Readings in Marketing Information Systems. New York: Houghton Miffiin Company, 1968 .

This book synthesizes literature germane to business information and intelligence systems, and relates it to marketing planning and strategy formulation. Selections are also included which stress the embryonic state of information systems development, plus the pitfalls involved in managing such networks and utilizing data emanating from them.

45. Stevenson, Noel C. How to Build a More Lucrative Law Practice. Englewood Cliffs, N.J.: Executive Reports Corporation, 1967.

A guide to attorneys to help establish basic business procedures, so as to convert financial. opportunities into higher and more equitable personal income.

46. Swimm, Charles H., et al. "Computerized Document Preparation," Law Office Economics and Management, Vol $x$, No. 4 (February 1970), pp. 411-437.

A description of how the computer is being used by some agencies for docket control.

47. Terry, George R. Office Management and Control. Homewood, Illinois: Richard D. Irwin, Inc. 1966.

A text concerned with the actions of administrative management. Part 3 , dealing with "The Office and Automation," was useful as background material; managing in the new office technology; the systems and procedures approach; the total systerns concept; source data automation; computers--technical considerations; computers-managerial considerations; and computerized office applications. Information is maintained in a single data stream by utilization of the total systems idea. 
48. Wilkins, Betty. "Current Comments," Law Library Journal, February 1968, p. 27.

Citations to all Florida legal periodicals on any topics or combinations thereof have been stored for retrieval of legal data in the University of Florida Computer Center. Designed for use by Florida attorneys, the project is currently being expanded to include Florida legal treatises. See 4 University of Florida Law Center News 2 (August 1967); 41 Florida: Bar Journal 81 (February 1967).

49. Williams, William F. Principles of Automated Information Retrieval. Elmhurst, Illinois: The Business Press, 1965 .

This book is intended to eradicate an imaginary and rapidly disappearing boundary line between data processing systems and information retrieval systems. Part 1 of the book is an introduction for the executive, while the remaining four parts of the book provide background and techniques for system designers and operationists. 
Appendix A. A REVIEW OF THE CORRESPONDENCE

During October 1969 the author initiated correspondence with 59 law firms, requesting information about thejr information storage and retrieval system. Surveyed were selected registrants attending the National Conferences on Law office Economics, held in 1965, 1967 and 1968. Selected were those firms which had indicated at the conferences, their progress in administrative areas. The sample group includes program leaders, guest speakers and lawyers whose firms have "advanced" administrative or information systems. These firms are all "leaders" in one respect or another in law office management.. The 59 requests were distributed over 23 states, to firms ranging in size from five lawyers to over 200 lawyers.

The concept of automated information storage and retrieval is a relatively new one for the legal profession. Although study has been under way for more than 10 years, it has only been within the last two years that the profession has shown any real interest. Insofar as most firms are still concerned with administrative problems, it was deemed that those firms which have already "solved" administrative problems would be the firms most likely to be working on the development of information systems. The 59 firms surveyed were selected from a total list of 290 registrants. Responses were received from 40 firms. 
Administrative Functions. Twelve firms report they are using data processing equipment, either their own or service bureau, for timekeeping and general ledger accounting. An additional four. firms reported using a manual timekeeping system. The remaining 24 respondents advise that they each have a manual bookkeeping system, which includes theix timekeeping function, at varying levels of sophistication. "Systems" range from "saving daily time tickets for future billing" to service bureau printouts of all relevant general ledger and billing/timekeeping information.

Only 10 firms indicated their use of automatic typewriters, e.g., IBM's MT/ST, in spite of the fact that all 40 firms advocated improved word processing efficiencies by using automatic typewriters.

Information Systems. Every respondent mentioned and discussed the use of an index card system for cataloging of office files. Several firms indicated a recent switchover from closed drawer files to open shelf files.

Only five firms felt they had a workable search and retrieval system for office-produced documents. They use

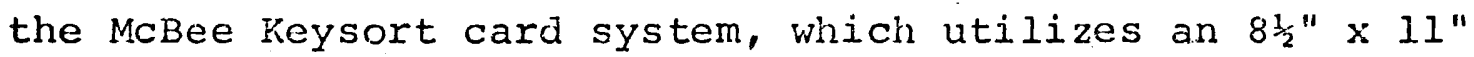
preprinted card with notches cut out of the four edges. BY sorting, and inserting an "ice-pick" in the appropriate holes, only the relevant cards will drop away, while the others are retained by the selector sorting needle. After reviewing the summary of information on the index card, a lawyer can immediately locate the information he is seeking, if 
it has been indexed.

of the five firms using the manual system, one firm indicated it took almost three years to record all of their office memoranda, opinions, and research notes. Their system contains over 3,000 index cards and a lawyer can search the entire file in less than 25 minutes. Their management committee discovered that with the volume of index cards that must be maintained, and the complexity of information needs, the needle sort system is inadequate. As a consequence, the firm has ordered an IBM 360, and is attempting to program for the computer their accounting requirements and library index system. The other four firms using the needle sort system have not yet completed all indexing, but feel that with what has been indexed, searches axe easier. Every respondent indicated the desire to be advised of any good working information system that might be considered usable for their firm.

Conclusions. Conclusions that have been drawn from the correspondence are:

1. Law firms are still trying to resolve administrative functional problems.

2. Only a few firms are satisfied with their present administrative systems.

3. No Iaw firm has a satisfactory office information retrieval system, although most firms employ a "workable" system. 
4. No law firm reported an automated information system capable of seaxching statutory and case law. Some governmental or institutional agencies have within the last year (1969) subscribed to computerized search services.

5. Every law firm is interested in developing an efficient, inexpensive, "information system." One problem is that each firm defines the need at a different level of sophistication, ranging from "what kind of shelf cabinets to use?" to "a definite need for a regional computerized system."

6. Individual law firms are not capable of producing an automated broad-base information system, and must look elsewhere for such a system.

When availabie, the respondent included samples of paper forms, flow descriptions of procedures, anä copies of materials relating to information or data systems they had investigated.

Table $I$ is a list of the firms responding, indicating the methods or aids used in areas of major management concern. One would think that there would be a correlation between the size of firm and use of administrative or information processing aids, but this survey does not so indicate. A correlation does exist between age of law firm management and use of "modern tools." The younger the managing partner (or members of the management committee), the more receptive is the firm to use a mechanical or computer systems approach. 
TABLE I

DATA GATHERED FROM CORRESPONDENCE AND INTERVIEWING INDICATING

METHODS OR AIDS USED IN AREAS OF MAJOR MANAGEMENT CONCERN

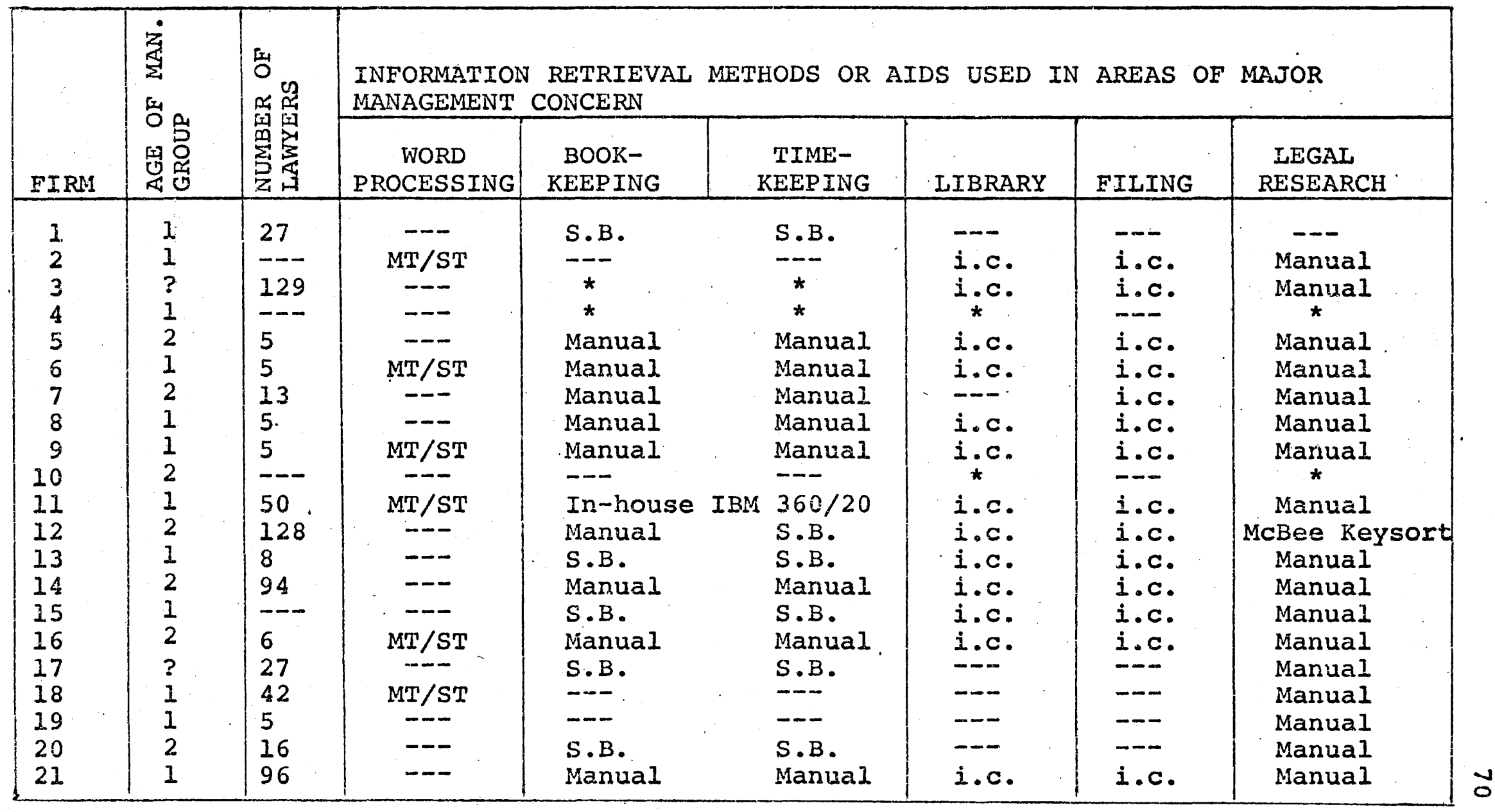




\begin{tabular}{|c|c|c|c|c|c|c|c|c|}
\hline \multirow[b]{2}{*}{ EIRM } & \multirow{2}{*}{ 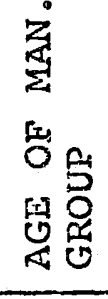 } & \multirow{2}{*}{ 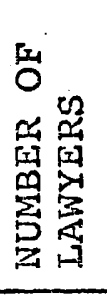 } & \multicolumn{6}{|c|}{$\begin{array}{l}\text { INFORMATION RETRIEVAI METHODS OR AIDS USED IN AREAS OF MAJOR } \\
\text { MANAGEMENT CONCERN }\end{array}$} \\
\hline & & & $\begin{array}{c}\text { WORD } \\
\text { PROCESSING } \\
\end{array}$ & $\begin{array}{c}\text { BOOK- } \\
\text { KEEPING }\end{array}$ & $\begin{array}{c}\text { TIME- } \\
\text { KEEPING }\end{array}$ & LIBRARY & EILING & $\begin{array}{l}\text { IEGAL } \\
\text { RESEARCH }\end{array}$ \\
\hline 22 & 1 & 5 & -- & Manual & Manual & $--\infty$ & $i . c$. & Manual \\
\hline 23 & 1 & 44 & -- & Manual. & --- & $-\infty$ & i. c. & Manual \\
\hline 24 & 1 & 37 & $\mathrm{MT} / \mathrm{ST}$ & In-house & IBM $360 / 40$ & i.c. & i.c. & $\begin{array}{l}\text { a. McBee Key- } \\
\text { sort } \\
\text { 360 } 140\end{array}$ \\
\hline 25 & 1 & 99 & $\mathrm{MT} / \mathrm{ST}$ & $\begin{array}{l}\text { NCR ACCtg. } \\
\text { Machine }\end{array}$ & ManuaI & i.c. & i.c. & Manual \\
\hline 26 & $?$ & 18 & --- & S.B. & S.B. & -- & -- & Manual \\
\hline 27 & 1 & 16 & $-\infty$ & -- & -- & -- & $-\infty$ & Manual \\
\hline 28 & 1 & 15 & -- & Manual & Manual & -- & -- & Manual \\
\hline 29 & $?$ & 15 & $\mathrm{MT} / \mathrm{ST}$ & S.B. & S.B. & -- & $i . c$. & Manual \\
\hline 30 & 1 & 1.4 & -- & -- & -- & -- & -- & McBee Keysort \\
\hline 31 & $?$ & --- & -- & -- & $-\infty$ & $-\infty$ & -- & OBAR \\
\hline 32 & 2 & --- & --- & $*$ & * & i.c. & i.c. & Manual \\
\hline 33 & 2 & 52 & -- & In-house & IBM 350 & -- & --- & Manual \\
\hline 34 & 1 & 7 & -- & --- & Manual & -- & -- & Manual \\
\hline 35 & 1 & 49 & -- & $N C R-500$ & system & -- & -- & Manual \\
\hline 36 & 2 & 39 & $\mathrm{MT} / \mathrm{ST}$ & Data Proces & ssing system & i.c. & $\begin{array}{l}\text { Alphabe- } \\
\text { tic }\end{array}$ & Manual \\
\hline 37 & $?$ & -- & --- & -- & --- & --- & -- & McBee Keysort \\
\hline 38 & $?$ & --- & -- & --- & --- & -- & -- & McBee Keysort \\
\hline 39 & 1 & 13 & $-\infty$ & S.B. & S.B. & $-\infty$ & -- & Manual \\
\hline 40 & $I$ & 22 & -- & -- & -- & -- & --- & OBAR (new) \\
\hline $41 \#$ & 1 & 46 & $\mathrm{MT} / \mathrm{ST}$ & Manual & NCR & i.c. & i.c. & Manual \\
\hline $42 \#$ & 1 & 33 & $M T / S T$ & Manual & Manual & i.c. & i.c. & Manual \\
\hline $43 \#$ & 2 & 31 & $M T / S T$ & Manual & Manual & $i \cdot c$. & $i \cdot c$. & Manual \\
\hline $44 \#$ & 1 & -- & $\mathrm{MT} / \mathrm{ST}$. & --- & & i.c. & i.c. & Manual \\
\hline
\end{tabular}




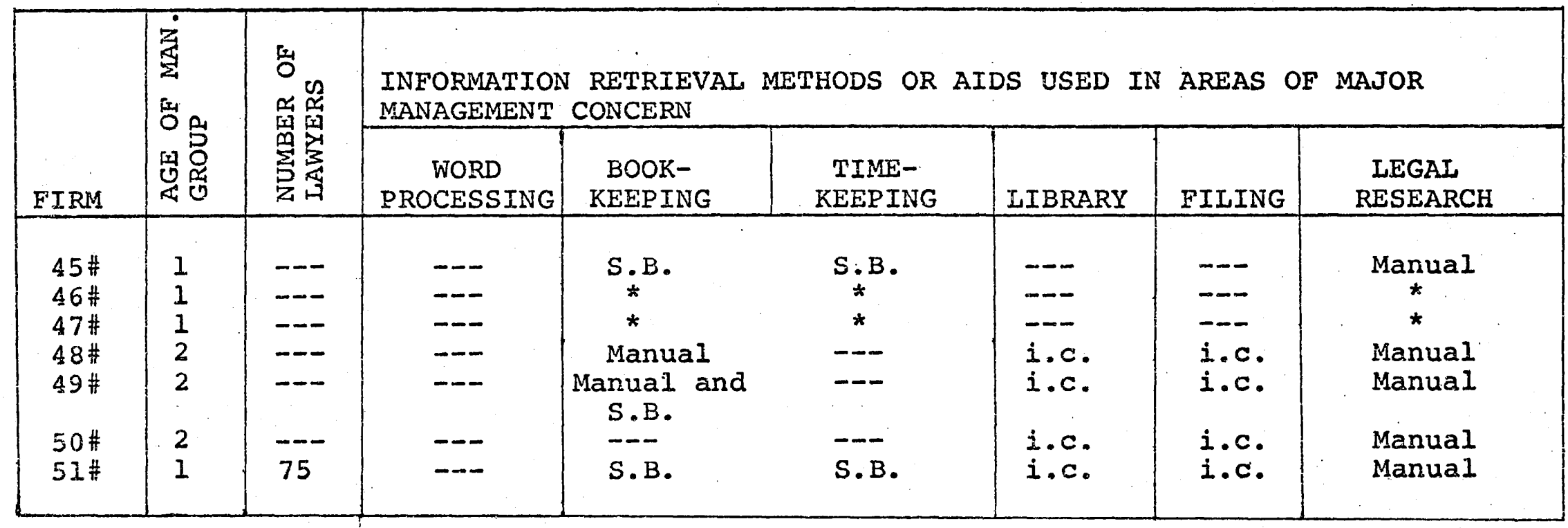

LEGEND

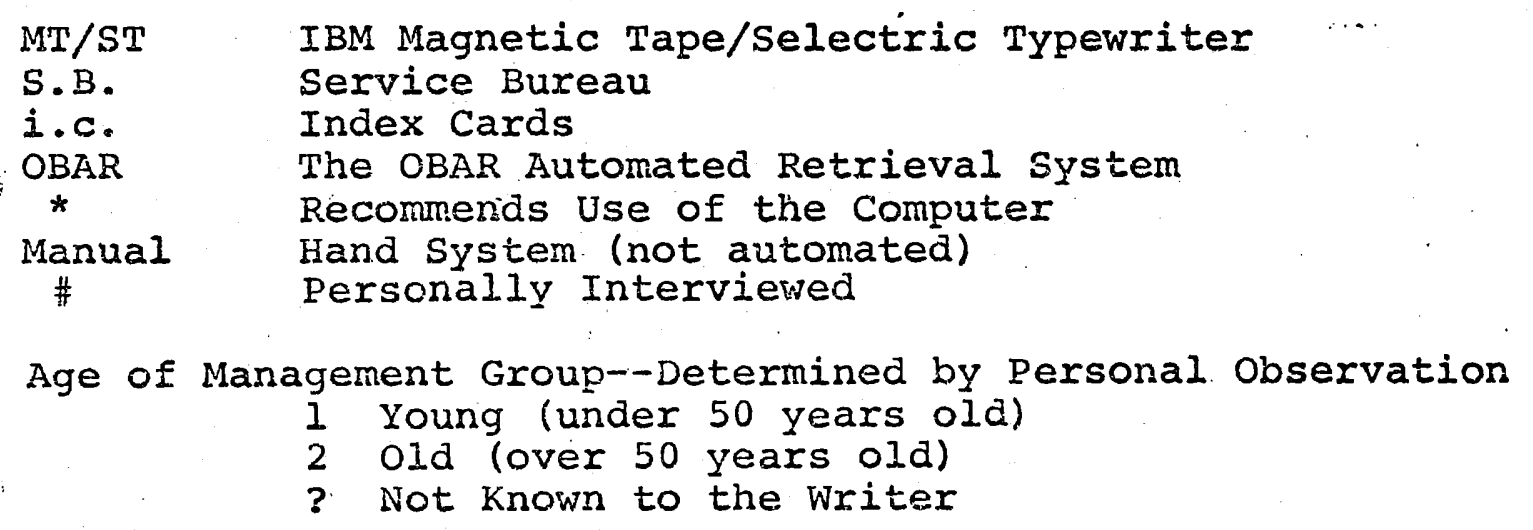


1 Adans, Duque and Hazeltine Los Angeles, California

2 Anerican Bar Association Chicago, Illinois

3 Baker, Botts, Shepherd \& Coates Houston, Texas

4 Bigelow, Robert P.

Boston, Massachusetts

5 Blackstock, Joyce \& Pollard Tulsa, Oklahoma

6 Burleigh, Carey \& Gooding La Grande, Oregon

7 Carrington, Johnson \& Stephens Dallas, Texas

8 Corey, Bylex \& Rew Pendleton, Oregon

9 DeMeo, DeMeo, Foster \& Waner Santa Rosa, California

10 Dickerson, F. Reed Professor of Law Indiana University

11 Dykema, Wheat, Spencer, Goodnow \& Trigg

Detroit, Michigan

\section{KEY TO EIRMS}

12 Fulbright, Crooker, Freeman, Bates \& Jaworski

Houston, Texas

13 Eulop, Rolston \& Burns Beverly Hilis, California

14 Gibson, Dunn \& Crutcher 634 South Spring Street Los Angeles, California

15 Halstead and Crocker Santa Ana, California

16 Hennessey, Curran, Jansen \& Kelly Spokane, Washington

17 Hill, Farrer and Burrill Los Angeles, California

18 Holman, Marion, Perkins, Coie \& Stone Seattle, Washington

19 Jones \& Maupin Los Angeles, California

20 Kadison, Phaelzer, Woodard \& Quinn Ios Angeles, California

21 Kixkland, Ellis, Hodson, Chaffetz $\&$ Masters

Chicago, Illinois 
22 Kottkamp \& O'Rourke

Pendleton, Oregon

23 Latham \& Watkins

Los Angeles, California

24 Lewis, Roca, Beauchamp, \& Inton Phoenix, Arizona

25 Mayer, Friedlich, Spiess, Tierney, Brown \& Platt Chicago, Illinois

26 Meserve, Mumper \& Hughes Los Angeles, California

27 Modrall, Seymour, Sperling, Roehl \& Harris

Albuquerque, New Mexico

28 Montgomery, Barnett, Brown \& Read New Orleans, La.

29 Murphy, Huiskamp, Stolper, Brewster \& Desmond

Madison, Wisconsin

30 Naman, Howell, Smith \& Chase Waco, Texas

31 Ohio Bar Automated Research Coilumbus, Ohio
32 Oregon state Bar

Portland, Oregon

33 Pillsbury, Madison \& Sutro San Francisco, California

34 Strong, Poelman \& Fox salt Lake City, Utah

35 Sullivan \& Cromwell New York, New York

36 Sutherland, Asbill \& Brennan Atlanta, Georgia

37 Texas State Bar Austin, Texas

38 Texas Trial Lawyers Association Austin, Texas

39 Voegelen, Barton, Harris \& Caliister Los Angeles, California

40 Wright, Harloz, Morris, Arnold \& Glander

Columbus, Ohio

41 Davies, Biggs, Strayer, Stoel and Boley

Portland, Oregon

42 King, Miller, Anderson, ivash \& Yerke Poxtland, Oregon 
43 Mautz, Souther, Spaulding, Kinsey \& Williamson Portland, Oregon

44 American Bar Foundation Directors, Messrs. Fried and Temporo Chicago, Illinois

45 Oregon--Public Utility Commission Asst. Director, Don Armstrong Salem, Oregon

46 Oregon--Executive Department Management Analyst, Don Mezirow Salem, Oregon

47 Oregon--Executive Department Asst. to the Directox, Kenneth Underdahl salem, Oregon

48 Oregon--Administrative Asst. to the Supreme Court, Mr. McCollough Salem, oregon

49 Oregon--Clerk to the supreme Couxt, Mr. Sercombe

Salem, Oregon

50 Oregon--Court of Appeals Chief Juage Schwab Salem, Oregon

51 Oregon--Attorney General, Lee Johnson Salem, Oregon 
Appendix B. COMPENDIUM OF EQUIPMENT AND TECHNTQUES

The need to better handle the volume and integration of both data and information is a problem not confined to large organizations with heavy computer investment. Very broadly, the spectrum of equipment covers:

1. the general office machines field

1. duplicators

2. adding machines

3. desk calculators, and bookkeeping and accounting machines

4. typewriters

5. automatic "word processor" typewriters, i.e., IBM's MT/ST, etc.

6. dictation equipment

7. service bureau, central word processing

8. high speed addressing equipment

9. Office copiers

10. punch card equipment

11. special filing equipment for visible filing, and reference document retrieval

12. microfilm

13. communication aids, i.e., facsimile machines and transcribers, and moving document devices

14. miscellaneous equipment, including paper cutters, paper punches, binding and 
folding equipment, etc.

2. the sub-computer spectrum

1. programmable, electronic-accounting machines, including peripheral memory devices, e.g., magnetic-striped ledger cards

2. equipment with electronic circuitry, with added computational ability and greater speeds

3. external storage devices, with randomaccess "memory"

4. small computers, e.g., IBM's System $360 /$ Model 20

3. the computer spectrum

1. "first generation;" relatively large in scale, vacuum-tube design, heavy reliance on punched card input/output, Iinited high speed magnetic-core or rotating drum internal memory, and reliance on machine language cocing rather than the later higher level simplified languages

2. "second generation," solid-state transistorized computers, incorporating use of random-access storage devices, central processors with expanded high speed magnetic-core storage, and use of symbolic 
languages

3. "third generation," featuring miniaturization, integrated circuitry, thin-film, high speed memory techniques, extremely large capacity ranäom-access storage. central processor able to provide on-iine, real-time access, and time sharing capabilities with remote terminals.

Today there are nine major producers of general puxpose computers, with specialization predonirantiy in software. $\vec{A}$ few of these manufacturers have systems installations for very small-scale users $(\$ 1,000-\$ 3,000$ monthly rental), srall-scale $(\$ 3,000-\$ 10,000$ per month), mediumscale users $(\$ 10,000-\$ 30,000$ per month), and large-scale users $(\$ 30,000$ and over, per month), thus offering a wide range of equipment and systems, that can by the use of the modularity structure, be "custom-designed" for any type business, or application.

1. Burroughs (Series 500 through $\mathrm{B}-8500$ )

2. Control Data Corporation--CDC---(Series 8090 through 6600)

3. General Electric (Series 115 through 645)

4. Honeywell (Series 516 through H-8200)

5. International Business Machines--IBM--(Series 1130 through $360 / 85$ )

6. National Cash Register---ivCR---(Series 500 through 
Century 200)

7. Radio Corporation of America--RCA--(Series 70/15 through 70/55)

8. Scientific Data Systems--SDS--(Serjes SDS 945 through SDS 940)

9. Sperry Rand's Univac (Series 9200 through $1108-11$.

Technological sophistication of the peripherals, and development of the systems approach also has an impact on the capacities and capabilities of the available equipment.

(a) input/output, source data acquisition, and display equipment, e.g., cathode ray tube units, video data terminals, graphics display terminals, and other television-type techniques; audio response systems; use of microfilm techniques; machine readable mark-sensing, optical font, magnetic ink-characters readers, optical page readers, and on-line terminals.

(b) time-sharing devices, which make it possible to communicate with, and use, a computer via a remotely located teletypewriter terminal unit.

(c) telecommunication: data, voice, and message transmission at extremely high speeds by use of such sophisticated devices as multiplexing 
equipment, automatic transmitters, typing and nontyping reperforators.

(d) data processing service centers, which are able to provide users access to computer equipment or service, without the capital investment, by charging a "usage" rate.

(e) data banks and information services, still in theix infancy, but very ljkely to have a tremendous impact on a "total system" for accumulation and use of mass computerized data/ information files.

(f) continuous improvements in program and software techniques. 